eCommons@AKU

January 2011

\title{
Viewpoint: my journey from the US back to Pakistan: what keeps me here
}

Saad Shafqat

Aga Khan University, saad.shafqat@aku.edu

Follow this and additional works at: https://ecommons.aku.edu/pakistan_fhs_mc_med_neurol Part of the Neurology Commons

\section{Recommended Citation}

Shafqat, S. (2011). Viewpoint: my journey from the US back to Pakistan: what keeps me here. Neurology Today, 11(22), 4-5. Available at: https://ecommons.aku.edu/pakistan_fhs_mc_med_neurol/85 


\section{My Journey from the US Back to Pakistan: What Keeps Me Here}

BY SAAD SHAFQAT, MD, PHD

$\mathbf{F}$ riends and colleagues were aghast when I informed them that I would be leaving the US to return to Pakistan. I had come here as a 24-year-old in 1989 to attend graduate school and completed my neurology residency and fellowship training at Massachusetts General Hospital in 2000. If I stayed in the US, undoubtedly, life would be easier - personally and professionally. But yet here I was booking my nearly 7,800-mile flight back.

vast majority of international medical graduates end up making America their adopted country.

The decision to return home is complex — and never taken lightly. Most people in my situation agonize over the pros and cons, weighing the obligations to aging parents and the comfort level of a familiar culture against the innate human drive for a better life. These days, America's mainstream dialogue might be dominated by unemployment figures,

\section{'Not many neurologists can say they had to delay rounds because Osama bin Laden was just hunted down near the nation's capital.'}

People find it hard to fathom why I would leave. But I had a ready answer for those who questioned my choice. An attractive job opportunity awaited, my wife was in agreement and, ultimately, it was home.

To a degree, I could understand why people were skeptical. For several decades, the US has been a magnet for fresh medical graduates like me from national debt, and political deadlock, but seen from the outside it is still the land of opportunity.

Returning to an academic position at an urban tertiary-level facility in Pakistan made the plunge easy for me. It was the kind of setting for which my neurology residency and fellowship training in Boston had prepared me well. Eleven years later, I have no regrets.

\section{'The decision to return home is complex} - and never taken lightly. Most people in my situation agonize over the pros and cons, weighing the obligations to aging parents and the comfort level of a familiar culture against the innate human drive for a better life.'

the developing world. Once the qualifying examinations are tackled and visa hurdles are cleared, you enter structured training that will transform you into a world-class professional, with the promise of work satisfaction and material comforts to follow. Although the situation is improving bit by bit, such advantages are still scarce in developing countries. No surprise that the
Pakistan is often in the news, and almost always for the wrong reasons. A militant insurgency based in the northwest has exported sporadic acts of terror to all corners of the country. There are natural disasters with crippling effects on the economy and the national morale. And while we have an elected government, it is hobbled by complicated coalition dynamics.
Yet this is still a nation of 180 million that sleeps and awakens like every other place in the world, where the business of life goes on no matter what. There may be gloom and doom but - as with the other routines of life the practice of neurology continues uninterrupted. There is a rhythm to it that provides focus and direction, and a sense of meaning that brings a certain fulfillment. The neurology division where I am based comprises six full-time and six part-time neurologists, most of whom are repatriates from the US. This has made it easy to implement training benchmarks and service standards that we all agree on.

Being part of a resourceful set-up helps. Aga Khan University Hospital, where I work, is located in Karachi, Pakistan's financial hub and its most cosmopolitan city. The institution was founded in 1985 and has become the country's major referral center. In 2006, it was certified by Joint Commission International, the global arm of the Joint Commission. A medical school and several residency and fellowship programs are in place.

Most of the time, my workday is like that of any other neurologist. If I am on-service, I go for rounds on the wards with a team of neurology residents, rotators, and medical students. Typical inpatient census is between 15 and 25, sometimes higher. The diagnostic list is dominated by stroke, epilepsy, and CNS infection (most often from tuberculosis). There is also a busy consult service, staffed by a separate neurologist; as elsewhere around the world, it is dominated by encephalopathy and surprises.

Some days it is my turn to conduct a dedicated teaching session. Although the applicant pool for our neurology residency program is small, the quality of our residents, who are invariably keen learners, is good. The program produced its first graduate in 1998 and since then has turned out an average of three residents per year. Some are practicing in Pakistan; a few have moved to the
Middle East; one has joined our faculty. Every now and then a medical student also comes along who is deeply interested in neurology; that is always a joy.

Outpatient neurology takes up the bulk of our time and the mix is not dissimilar to what one would see in the US - neck and back ache, psychosomatic complaints, headache, stroke, epilepsy, Parkinson disease, dementia, multiple sclerosis, motor neuron disease, peripheral neuropathy, myasthenia gravis. Most patients are self-paying, so finances are invariably limited, which forces judicious test and drug selection and demands constantly evolving strategic thinking. The basic tools of neurology - CT, MRI EEG, and EMG — are at hand, for which we are grateful, because they are a luxury in Pakistan.

Neurological therapies taken for granted in many parts of the world are also often out of reach, including intravenous immunoglobulin for Guillain-Barré syndrome, beta-interferon for multiple sclerosis, tissue-plasminogen activator for acute stroke, and cholinesterase inhibitors for dementia. At many hospitals, including ours, a welfare budget for indigent patients usually kicks in. But not everybody is so lucky.

Occasionally, I am reminded of how bizarre things can get. Not many 
neurologists can say they had to delay rounds because Osama bin Laden was just hunted down near the nation's capital. The disorienting nature of the news often leaves little room in my head for anything else. It is also extremely disturbing when terrorism rears its frightening head - a suicide bomber killing scores, a major political figure assassinated, urban gang wars in which the police are unable or unwilling to do much. These are the daily realities my colleagues and I face. We have no choice but to take them in stride and continue with our lives, but we long to be rid of them.

Despite the clinical load and the disturbing news cycles, there is still time and inclination for research. The level of motivation varies from person to person, but everybody is able to publish competitively, and some have been able to attract grants. Last year we were delighted to secure NIH funding for a cerebrovascular fellowship training program, designed in collaboration with US-based colleagues. Our institution has set up infrastructure and a processing office to facilitate grant submission; sometimes this is a help, sometimes not.

Faculty affairs are dominated by the universal issues - promotion, compensation, and search committees for leadership appointments, with occasional forays into parking, cafeteria facilities, and who might have done what to whom. An elaborate university and hospital governance system exists to ensure optimum outcomes for all difficulties. Sometimes it serves its purpose and sometimes not.

Admittedly, the lure of relocating to the US is ever-present and once in a while someone gives in. This triggers a period of reflection among the rest of us in which we are forced to re-examine our circumstances with an unemotional eye. There is nothing cerebral or highminded about it, because the calculations are inevitably mundane.

Although it is hard to pry out what lies behind a mid-career professional's relocation to the US, most people cite safety and security issues when they leave. A few will also acknowledge the enticement of high earnings. Granted they had foregone these same high earnings when they had initially moved back to Pakistan, but after a few years of earning locally, age can suddenly catch up with you, unleashing anxiety about the future of your children and your retirement plans.

When you ask US-returned physicians in Pakistan what made them come back, most say it is because of family ties. This seems logical enough at first glance, but since everyone has family ties yet only a handful return, this could not possibly be an adequate explanation. So what brings us back and what keeps us here? For many of us, there is an internal visceral compass that continues to point unfailingly towards home. Sometimes you just have to follow a visceral urge. Perhaps that is all we are doing. That is what I did, and I've never regretted it. •

Saad Shafqat, MD, PhD, is a professor in the department of medicine (neurology) at Aga Khan University Medical College in Karachi, Pakistan

\section{WE WANT YOUR INPUT}

We want to hear from you. Please feel free to respond

to our stories by writing

NeuroToday@LWWNY.com. 